\title{
Recognition of Older Adults as a Heterogeneous Social Group
}

\author{
Sanja Ivic ${ }^{1}$ \\ Goran Nikolic ${ }^{2}$ \\ Milan Igrutinovic ${ }^{3}$
}

\begin{abstract}
Human rights of older adults are still not sufficiently developed. This paper will explore how the rights of older adults are regulated by European law and whether European law sufficiently recognizes older adults as a heterogeneous social group. The population of the European Union is growing older. According to the European Commission's reports, age discrimination in Europe is widespread. Therefore, the concept of work and retirement system as well as the perception of older adults should be transformed. Discrimination against older adults and various forms of inequality are amplified by the COVID-19 pandemic.
\end{abstract}

Keywords: Older adults. Rights. Identity. Heterogeneous. European Union.

\section{INTRODUCTION}

In 2009, European Commission announced that age discrimination in Europe is widespread (EUROPEAN COMMISSION, 2009a). "In 2019, more than one fifth $(20.3 \%)$ of the EU-27 population was aged 65 and over

${ }^{1}$ Institute for European Studies, Belgrade - Serbia. (D) https://orcid.org/0000-0003-1504-0059. E-mail: sanja_ivic1@yahoo.com.

2 Institute for European Studies, Belgrade - Serbia. (D) https://orcid.org/0000-0001-9312-2194. E-mail: goranvnikolic@gmail.com.

3 Institute for European Studies, Belgrade - Serbia. (D) https://orcid.org/0000-0002-7487-518X. E-mail: milan.igrutinovic@gmail.com.

https://doi.org/10.1590/0101-3173.2021.v44n4.29.p357 
[...] The share of people aged 80 years or above in the EU-27's population is projected to have a two a half fold increase between 2019 and 2100, from $5.8 \%$ to $14.6 \%$." (EUROSTAT, 2020). According to the UN OpenEnded Working Group on Ageing, "[...] age discrimination is widespread in European societies and it can affect people at all stages of life, in employment as well as in other spheres." (EQUINET, 2019).

Ageism is a concept identified by Robert Butler in 1969. It is a socially constructed term, which points to marginalization and discrimination of older adults based on their age (PHELAN, 2008, p. 322).

\begin{abstract}
Ageism and ableism also exhibit the border anxiety of the abject. For in confronting old and disable people I confront my own death. Kristeva believes that the abject is connected with death, the disintegration of the subject. [...] Thomas Cole (1986) shows that prior to the nineteenth century old age was not linked to death; indeed, just the opposite was the case. In a time when death might come to persons at any age, and often took children and young adults, old age represented a triumph over death, a sign of virtue. [...] Now, when it has become increasingly likely that people will live to be old, old age has become associated with degeneracy and death. (YOUNG, 1990, p. 147).
\end{abstract}

Ageism is founded on the sharp dichotomy young/old, where the first term is perceived more desirable and valuable. This dichotomy involves illusory correlation and interpretation based on stereotypes. "Dominant and powerful discourses present older adults as a homogeneous entity characterized by senility, mental incapacitation, asexuality and unemployability." (PHELAN, 2008, p. 522). Those discourses represent the violation of the article 3 (Right to integrity of the person ${ }^{4}$ ) of the Charter of Fundamental Rights of the EU.

Ageism and idea of older adults as a separate category are mere mental constructs. As mental constructs, they can be changed, reconceptualised and reintroduced in order to recognize the diversity of older adults that can be categorized in various ways, not primarily by their age. According to Iris Marion Young, the nature of social groups is shifting and fluid (YOUNG, 1990, p. 9). Social groups are not static, but constantly redefined and reinterpreted in relation to one another. However, this fact is not sufficiently recognized within the European legal discourse.

4 "Everyone has the right to respect for his or her physical and mental integrity." (EUROPEAN UNION, 2000). 


\section{Representation of the Older Adults in European LaW}

Older adults represent a heterogeneous and polyphonic social group. Representatives of this group are different and cannot only be identified and classified by their age. The old age cannot be defined relying on universal concepts. It should be perceived contextually and multiple layers of identities should be taken into account (gender, ethnicity, occupation, and so forth).

However, older adults are often defined as a homogeneous social group within legal texts. For instance, the Charter of Fundamental Rights of the European Union considers older adults as a homogeneous group within Article 25 (Rights of the elderly) (IVIC, 2016). Article 25 states: "The Union recognizes and respects the rights of the elderly to lead a life of dignity and independence and to participate in social and cultural life." (EUROPEAN UNION, 2000).

However, the concept of "the elderly" includes different narrative practices, interests and experiences, and this is not recognized by the Charter of Fundamental Rights of the European Union. The concept of the elderly includes different groups of older adults such as immigrants, refugees, mentally disable older people, and so forth (IVIC, 2016). "The idea of older adults presented within the Charter of Fundamental Rights of the EU does not take into account multiple discrimination from which older adults suffer." (IVIC, 2016, p. 190). The EURAG, a European organization that represents the interests of older persons, established the Charter of the Elderly (EURAG, 2005). However, the heterogeneous nature of older adults as a social group is not sufficiently recognized by the EURAG Charter of the Elderly.

Article 21 (Non-discrimination) $)^{5}$ of the Charter of Fundamental Rights of the European Union does not solve the problem of implicit discrimination against older adults (IVIC, 2016, p. 192). The Charter of Fundamental Rights of the EU separates the rights of older adults, the rights of the children and women's rights (which are determined in the Chapter III) from citizen's rights (which are defined in the Chapter V) (IVIC, 2016, p. 192).

Another problem is represented by gender inequality. Women often receive smaller pensions than men do. This is caused by the gender pay gap. "The gender gap in pay has narrowed since 1980, but it has remained

\footnotetext{
5 "Any discrimination based on any ground such as sex, race, color, ethnic or social origin, genetic features, language, religion or belief, political or any other opinion, membership of a national minority, property, birth, disability, age or sexual orientation shall be prohibited." (EUROPEAN UNION, 2000).
} 
relatively stable over the past 15 years or so. In 2018, women earned $85 \%$ of what men earned, according to a Pew Research Center analysis." (GRAF et al., 2019). Women also have less advantageous pension insurance conditions (COUNCIL OF EUROPE, 2005). The higher percent of older persons $(55 \%)$ are women, and this should be taken into account in all definitions of the rights of older adults (COUNCIL OF EUROPE, 2005). Article 23 (Equality between men and women) ${ }^{6}$ of the Charter of Fundamental Rights of the European Union is still not fully applied and is still not part of reality and everyday life. A formal guarantee of equality and rights is not sufficient, because it often implies "mechanical interpretation of fairness." (YOUNG, 1990, p. 11).

Societies should establish more active role of older adults in social, cultural and political domain (IVIC, 2015). "Although many countries currently have universal healthcare systems, these systems are beginning to feel the strain of an increasingly aged population, and there is some question about how these systems will be maintained in the future." (HREA, 2003). The European Social Charter establishes the system of medical care and social security, relevant for older adults (IVIC, 2016, p. 191). However, the availability of informal care will be reduced, due to social and political changes in the EU, such as: higher participation of women in labour force, increased mobility and changes in family structures (COMMUNICATION COM, 2009).

Some social groups (such as persons with disabilities, children, older adults and so forth) are particularly vulnerable to inhumane treatment (IVIC, 2015, p. 167). According to Mégret, this inhumane treatment, “[...] may also involve more discreet forms of neglect (e.g.: malnutrition, insufficient medical care) and be of a predominantly psychological nature (intimidation, humiliation).” (MÉGRET, 2010, p. 8). Mégret argues that “[...] developing a human rights regime that is adopted to the needs of the elderly should be seen as part of the larger fragmentation of the human rights project, as the latter increasingly seeks to apply to select populations (women, children, persons with disabilities, migrant workers, indigenous peoples, sexual minorities, etc.).” (MÉGRET, 2010, p. 2).

6 "Equality between men and women must be ensured in all areas, including employment, work and pay; The principle of equality shall not prevent the maintenance of adoption of measures providing for specific advantages in favor of the under-represented sex." (EUROPEAN UNION, 2000).

7 The European Social Charter, Article 11, 12, 13, 14 and additional protocol to this charter, 1998 (part II, Article 4). 
Older adults play multiple roles as a heterogeneous social group - in employment, as beneficiaries of social services and so forth. This necessitates specific legal framework for their protection as a matter of practical policies. This legal framework would reduce the impact of negative stereotypes. Although some governments have supported the rights of older adults, such as free or discounted medical care and social security, those systems relied on the presupposition that older persons represent lower percent of population than young and middle-aged individuals (HREA, 2003). That is why they are not well prepared to meet the needs of the growing aged population (IVIC, 2015). Furthermore, societies should establish more active role of older adults in cultural, social and political spheres (IVIC, 2015). "Although many countries currently have universal healthcare systems, these systems are beginning to feel the strain of an increasingly aged population, and there is some question about how these systems will be maintained in the future." (HREA, 2003).

The European Social Charter ${ }^{8}$ establishes the system of medical care and social security, relevant for older adults. However, the availability of informal care will be reduced, due to social and political changes in the EU, such as: higher participation of women in labour force, increased mobility and changes in family structures (COMMUNICATION COM, 2009).

\section{Discrimination Against Older Adults}

The UN Department of Economic and Social Affairs (UN DESA) that represents the home of the Sustainable Development Goals (SDGs) identified the rights of older persons as particularly vulnerable during the COVID-19 pandemic crisis (UNITED NATIONS, 2020). "The public discourse during COVID-19 misrepresents and devalues older adults." (FRASER et al., 2020). It portrays older people as a burden on society, weak and unimportant (UNITED NATIONS, 2020). When the COVID-19 pandemic emerged, older persons were portrayed as victims of the virus, while it was argued that younger people have decreased risk of infection (FRASER et al., 2020). This point of view reflects ageism as it has been proven false as younger people are also the victims of the COVID-19 pandemic (FRASER et al., 2020).

The COVID-19 is labeled "[...] as the 'Boomer Doomer', 'Senior Deleter' and 'Elder Repeller”' (MEISNER, 2020) on social media. However,

8 The European Social Charter, Article 11, 12, 13, 14 and additional protocol to this charter, 1998 (part II, Article 4). 
the most viral label was "Boomer Remover" (MEISNER, 2020), which circulated widely on social media (MEISNER, 2020). Some politicians said that older persons should be willing to sacrifice themselves for the sake of economy and younger generations (MEISNER, 2020). This is another example that contributions of older people are not valued. Some recommendations regarding the COVID-19 pandemic medical intervention in situations of limited resources emphasize that "[...] it might be needed to set an age limit for the admission to intensive care." (CESARI; PROIETTI, 2020, p. 576).

According to article 1 of the Universal Declaration of Human Rights, "all human beings are born free and equal in dignity and rights" (UNITED NATIONS, 1948). This right also adheres to older persons, and does not change with age. The COVID-19 pandemic reveals social inequalities and divisions, which are only amplified by the crisis.

The question of inequality is not just economic, social and political question. The symbolic aspect of inequality must be taken into account because it includes metatheoretical presuppositions based on binary oppositions that work from within the discourse of law and undermine the basic rights guaranteed by the law (IVIC, 2016). This symbolic oppression implies binary logic, which forms hierarchical thinking founded on the sharp binary oppositions such as: young/old, citizen/alien, self/other and so forth, in which the first term is perceived as desirable and valuable, while the second term is rejected (IVIC, 2016, p. 193).

Binary oppositions are mostly re-examined by Lévi-Strauss. LéviStrauss argues that mythical thought consists of binary oppositions, which can be considered its basic elements (IVIC, 2016). According to Lévi-Strauss, binaries are universal and they are made in all human societies, regardless of historical period and geographical space (IVIC; 2016). According to Baudrillard, binary oppositions are resolved within the domain of symbolic (IVIC, 2016). "Western metaphysics is based on binary oppositions, where opposed terms are not equally valued. One of the terms is dominant, while the other is subordinated and defined by the negation of dominant term." (IVIC, 2016, p. 23). Thus, the old is defined as the young's Other.

René Descartes and John Locke define the notion of identity as fixed, and based on various binary oppositions. Descartes defines subjects as 
"thinking thing." 9 He argues that rationality and consciousness are the basic characteristics of all human beings. Consequently, binary oppositions arise: rational/irrational, mind/body, conscious/unconscious and so forth (IVIC; 2016, p. 23). Only the first terms in those binaries are considered human characteristics. Those individuals who represented the second terms of those binary oppositions were excluded from society and legal discourse (IVIC, 2016).

John Locke also defines humanity by rationality. He defines "person" as "[...] a thinking intelligent being, that has reason and reflection, and can consider itself as itself." (LOCKE, 1975, p. 322) Locke emphasizes that consciousness makes personal identity, because it unites diverse experiences and actions into one person. Both Descartes and Locke do not acknowledge irrational and unconsciousness aspects of human identity. Both philosophers also perceive identity as permanent, fixed and static. This point of view sharply divides young from old, reason from emotion, mind from body, and so forth.

Feminist poststructuralists are mostly concerned with power and they emphasize that identities and meanings are socially and historically constructed (WEEDON, 1996). Thus, they are always open to rereading and reinterpretations. Poststructuralists recognize the existence of symbolic oppression in Western discourse and law (WIERINGA, 1998). This symbolic oppression is reflected in binary oppositions (male/female, young/old, good/ bad, public/private, nature/culture, etc.). Poststructuralists argue that those binary oppositions are not fixed - they are constructed. Therefore, they can be transformed.

According to poststructuralists, meaning is constituted within language (WEEDON, 1996). Language does not reflect our social reality. It constitutes our social reality. However, this constitution is a political act and it involves power relations. Although poststructuralists argue about the impossibility of fixed meaning, they do not argue about the disappearance of meaning, but about the challenge and constant reinterpretation of discourse within which the meaning is produced. Thus, reality is produced by language (FOUCAULT, 1972). This production is a political act and it involves power relations based on binary oppositions (FOUCAULT, 1972). Post structuralism can help question some of the main concepts of European law. It has to be emphasized

9 "But, what, then, am I? A thinking thin, it has been said. But what is a thinking thing? It is a thing that doubts, understands, conceives, affirms, denies, wills, refuses; that imagines also, and perceives." (DESCARTES, 1901, p. 28). 
that the main concepts, which European law contains, are not fixed, they are constructed. That means that they can constantly be redefined and changed. The poststructuralist perspective is significant for creating a new narrative about the older adults.

A number of studies shows that narratives can be used for changing behavior, attitudes, judgments and social actions (SHAFFER et al., 2018). They may also be used for reducing prejudices "by inducing the reader to imagine the experiences of another person, increasing the perceived connection between the reader and the person in the narrative." (SHAFFER et al., 2018, p. 431). New narratives that overcome this binary distinction and argue that we are all aging, and this is not about older people, but about all of us, should be advocated in public discourse. "People's behavior is influenced by social norms: what they perceive that others are doing or what they think that others approve or disapprove of." (BAVEL at al., 2020). For this reason, developing a new narrative about older persons needs to be tied to social and legal norms. Thus, the development of the United Nations Convention of the Older People is necessary. It will increase social equity and define the term older adults in polyphonic manner, acknowledging various aspirations, experiences, occupation and affiliation of older people. It will lead to improving the rights of older persons, increased monitoring across countries and the rise of consciousness about the role of older persons in the society. It will also encourage developing new policies on ethical criteria regarding medical help and care, which will prevent making medical decisions on non-medical reasons. Governments and civil societies should make efforts in developing new narrative about older people within public discourse. A number of retired doctor and nurses had a significant role in combating COVID-19 pandemic. Older people contribute to the volunteer sector, pay taxes and contribute to their communities in various ways.

Creating a new narrative is a strategy used by the EU in order to strengthen European identity and bring Europe closer to its citizens (BARROSO, 2013). Another strategy based on creating a new narrative is "Changing the Narrative in Colorado." (CHANGING THE NARRATIVE, n.d.). This initiative aims at changing the narrative about aging and older people already exist. It was launched by eight aging organizations whose goal was changing narratives about aging and ageism in light of demographic change. Creating a new narrative about older adults is necessary for social change. 
The heterogeneous idea of the term older adults should be developed within the framework of both European and international legal discourse. Only in these way sharp binary oppositions, stereotypes and marginalization will be overcome. Older adults should not be perceived as a monolithic social group, because this social group embraces different individuals who represent various points of views, interests, narratives, talents and experiences. Defining those people only by their age within the legal discourse leaves room for exclusion and multiple discrimination.

\section{Population Ageing in Europe}

The economic background to binary oppositions mentioned in the previous section has its roots in the modernist conceptions of identities that relate citizens to work, to their abilities to produce new value. "The retirement and social welfare, as institutions, created a special social and economic space for the older adults." (PHILLIPSON; BIGGS, 1998, p. 13-14). These institutions over time had developed consumer-centric logic (HUDSON, 2009) On the other hand, the older adults had become staples of the old welfare system under threat from the stricter fiscal logic that has also pressured the rise of the retirement age, adding to the complexity of the employment of older adults (HUDSON, 2009). This is accompanied by partial privatisations of pension funds, opening welfare services to the market forces and rise of the social economy organizations within the markets (HUDSON, 2009). That has moved the old age identities further into the more indeterminate and less secure social position, having in mind the dominant role of the socially and economically constructed aspect of ageing in relation to the biological and chronological ones (SCHALK et al., 2010, p. 80). Barrett has linked those roles, arguing that research has consistently found that "[...] occupying lower socioeconomic strata was associated with having older identities", that "[...] those in later life are disadvantaged not only by the objective conditions of their lives but also by conceptions of their aging selves", and "[...] that the less advantaged tend to have older identities than their more privileged peers." (BARRET, 2003, p. 107).

Population aging is one of the biggest social, political and economic challenges facing the European Union (EUROSTAT, 2020). "There is a growing number and share of older persons (aged 65 and over), with a particularly rapid increase in the number of very old persons (aged 85 and 
over).”(EC.EUROPA.EU, 2018a). These demographic developments will have a significant impact on labour markets, pension and social security systems, health and care requirements of the older persons, healthcare services and so forth (EC.EUROPA.EU, 2018a). Population ageing began several decades ago in Europe and this trend is visible in the transformations of the age structure of the population (EUROSTAT, 2020). It is also reflected in an increasing share of older adults in overall demographics (EC.EUROPA.EU, 2018b).

The growth in the relative share of older people may be explained by increased longevity and consistently low levels of fertility over many years. The median age in the EU-28 (42.6\% year 2016) increased by 4.3 years between 2001 and 2016. The old-age dependency ratio (used to study the level of support given to older persons by the working age population) for the EU-28 was $29.3 \%$ on 1 January 2016 (there were 3.5 persons of working age for every person aged 65 or over). The old-age dependency ratio significantly increased during the past decade and it is projected to almost double by 2080. (EC.EUROPA.EU, 2018b).

It is a clear tendency that ageing has been accelerating for decades, which put the pressure on the welfare systems (FARGUES, 2011). Population ageing in Europe leads to decrease in the workforce in Europe. "The largest decrease is expected to occur during the 2015-2035 period, when the baby-boom cohorts will be entering retirement." (COMMUNICATION COM, 2009). Ageing populations will increase public spending in terms of health and pension expenditure, which might put the burden on future generations (FARGUES, 2011). According to Špidla, former Commissioner for Employment, Social Affairs and Equal Opportunities:

In dealing with the short-term challenges of the economic crisis, we must not forget the long-term challenge of ageing. Simply sending people into early retirement - as we have done in the past - is not a solution this time round. We need to emerge from this crisis with more and better employment opportunities for older people. In ageing society, everyone needs a chance to take part in the labour market. (EUROPEAN COMMISSION, 2009b).

The European Union started to prepare for major social, budgetary and economic challenges, which will arise from the combination of law birth rates and ageing (IVIC, 2016, p. 183). These demographic trends will increase 
public spending in housing, education and health and pension expenditure (COMMUNICATION COM, 2009). Slow economic growth makes these challenges even more serious. Some Member States already reformed their pension systems and many of them attempt to establish better balance between family and professional life (COMMUNICATION COM, 2009). Member States will build strategies in order to reform long-term care and health care (COMMUNICATION COM, 2009). They will also develop strategy for youth and education. In the post-industrial age, divisions in the society are not based on class. They are based on life opportunities.

The EU population will continue to age (EUROSTAT, 2015).

During the period from 2016 to 2080 , the share of the population aged 65 years or over will account for $29.1 \%$ of the EU-28's population by 2080 , compared with $19.2 \%$ in 2016 (and 16.8\% 2006). Another aspect of population ageing is the progressive ageing of the older population itself. The share of those aged 80 years or above in the EU-28's population is projected to more than double between 2016 and 2080, from $5.4 \%$ to 12.7 \%. (EC.EUROPA.EU, 2018c).

Joan Costa-Font, Edward C. Norton, and Luigi Siciliani (2017) emphasize that pressure for reforms related to extending the role of the public sector in healthcare

[...] comes from increasing demand as a result of population ageing and a reduction in the supply of informal care [...] There is a clear role of the government in the financing, and to a lesser extent in the organisation, of long-term care services. However, the introduction of some redistributive public funding designs can pose a threat to the financial sustainability of such systems, especially in the longer run. Similarly, it is important to pay attention to the design of subsidies and supports, as unconditional care-giving subsidies in cash affect saving motivation. (COSTA-FONT; NORTON; SICILIANI, 2017).

In addition, "[...] publicly funded system fare better on equity of access. Similarly, the organisation of long-term care indicates that the not-forprofit status of an organisation and the degree of hospital autonomy influence service delivery to a large extent." (COSTA-FONT; NORTON; SICILIANI, 2017). 
However, demographic challenge seems less threatening if the EU is perceived as dynamic (not static) political community. The European political community has continuously changed from the Treaty of Paris (formally the Treaty establishing the European Coal and Steel Community), which was signed on 18 April 1951 to the Treaty of Lisbon, which was signed on 13 December 2007. The EU as a political entity represents contingent and flexible category, which is constantly transformed. The EU changes with accession of every new Member State. It is also transformed by new challenges and goals. Consequently, the nature of the EU cannot be described and analysed by univocal perspectives based on sharp distinctions.

The nature of ageing is changing as well. According to Giddens (2007), the concept of retirement could be rejected in future. It will be replaced by more flexible attitudes about work. There will be no sharp distinctions between working and non-working periods in life (GIDDENS, 2007). The future of the European social model is not only based in investing in young people, but also on relying on intellectual and professional capacities of older adults (IVIC, 2015). A number of Member States prolonged working life for this reason and this strategy will be employed in the EU in future. Consequently, the rate of older workers will grow (IVIC, 2015). Post-industrial society requires revising attitude towards older adults. This point of view strongly rejects the idea represented by some authors that older adults should be excluded for social citizenship and that society should be focused on young ${ }^{10}$ (CALLAHAN, 1987; JECKER, 1988).

These facts point to significance of establishing the rights of older adults within European legal discourse ${ }^{11}$, which will not contain oppressive metatheoretical presuppositions.

The problem of ageing Europe found its way in the EU party politics. For instance, European Seniors Union (ESU) aims at promoting the rights of

${ }^{10}$ On the other hand, older adults can also represent a powerful group in society. However, this paper focuses on ageism, which accelerates in contemporary societies mostly guided by youth imperialism dictated by the media and consumer society.

${ }_{11}$ The rights of older adults are still neglected within both the international and European law, although some efforts for their development had been made. "Vienna International Plan of Action on Ageing" is adopted by the World Assembly on Ageing in 1982. In 1991, the UN Principles for Older Persons were established. A General Comment on the rights of older adults is issued by the Committee on Economic, Social and Cultural rights. Furthermore, "Madrid International Plan of Action on Ageing" is established. There are also some private international law instruments which focus on the rights of older adults, such as the Hague Convention on the International Protection of Adults (2000) (MÉGRET, 2010). 
older adults in Europe within European People's Party alliance (EUROPEAN SENIORS' UNION, 2018). It is

[...] dedicated to the advancement of senior citizens rights throughout Europe and the promotion of senior-related issues within the European Peoples Party.. ESU adheres to the historic mission of the EP of creating a united and federal Europe that is based on freedom, justice, solidarity, responsibility, equal opportunities and the principle of subsidiarity. ESU shares the basic values and principles of EP and is recognized by the EP as the official association of senior citizens from all like-minded political parties in Europe. (EUROPEAN SENIORS' UNION, 2018).

However, ESU does not strictly confine itself to the matters relevant to older people, but rather venture into wider array of issues (EUROPEAN SENIORS' UNION, 2018). At its Congress in November 2016, ESU highlighted a number of points relevant to the population of the European Union (EUROPEAN SENIORS' UNION, 2018). ESU initiated more discussions on the future of Europe based on trans-generational dialogue with effective and transparent policies. It brought to light the problems of refugees and the persons on the sidelines of the labour market. It also initiated more discussions on the EU security and defence policies based on the balanced approach between "[...] preventive and repressive measures", and supported the principles of good governance, rule of law and respect for the human rights (EUROPEAN SENIORS' UNION, 2018, 2016, p. 4).

The political party 50Plus in the Netherlands advocates the rights of pensioners. After 2017 elections in the Netherlands, it is tenth strongest political party in this EU member state (NOBLE, 2017). The basis of the campaign of this political party was the promotion of the rights of older persons, using terms like "second-class citizens" to describe their position (PIETERS, 2016). It emphasized that older persons "have every right to face their future with fear and trembling if 50Plus does not make it into the next cabinet" (PIETERS, 2016). One of the main goals emphasized by this campaign was stopping of "pension robbery", a fixed number of seats for the older persons in public transportation and so forth (PIETERS, 2016).

The EU promotes active ageing and has previously designated 2012 as the European year for "active ageing and solidarity between generations" (EUROSTAT, 2012). "It highlighted the potential of older people, promoted their active participation in society and the economy, and aimed to convey 
a positive image of population ageing. "The innovation union is one of the Europe 2020 flagship initiatives" (EUROSTAT, 2012). In 2012, the European Commission adopted a Communication on taking forward the Strategic Implementation Plan of the European Innovation Partnership on Active and Healthy Ageing (EUROPEAN COMMISSION, 2012). Initiatives that promote active aging are significant for overcoming negative stereotypes and developing a new narrative about older adults. "Active ageing is an important area of social investment [...] For those senior citizens who remain in good health, some will decide to continue at work or become active in voluntary work, while others may join a variety of social groups, return to education, develop new skills." (EUROSTAT, 2015, p. 134).

\section{Conclusion}

This paper argues about the need for establishing the heterogeneous idea of social groups based on idea of fluid identity within the framework of both European and international legal discourse. Only in these way sharp binary oppositions, negative stereotypes and marginalization of older adults will be overcome. The first part of this paper analysed rights of older adults defined by the EU legal discourse. Older adults should not be perceived as a monolithic social group, because this social group embraces different individuals who represent various points of views, interests, narratives, talents and experiences. Defining those people only by their age within the legal discourse leaves room for exclusion and multiple discrimination. The second part of this paper showed that the entire European idea of identity is based on binary oppositions by which certain groups and individuals are excluded and marginalized. It is argued that poststructuralist idea of flexible, heterogeneous and polyvalent identity leads towards better understanding of social groups such as older adults. It is also significant for creating a new narrative about older adults. Third part of the paper explored the economic background to binary hierarchies as well as some possible solutions to problems of an aging population in Europe. 
IVIC, S.; NIKOLIC, G.; IGRUTINOVIC, M. Reconocimiento de los adultos mayores como grupo social heterógeneo. Trans/form/ação, Marília, v. 44, n. 4, p. 357-374, Out./ Dez., 2021.

Resumen: Los derechos humanos de las personas mayores aún no están suficientemente desarrollados. Este artículo explorará cómo los derechos de los adultos mayores están regulados por la legislación europea y si la legislación europea reconoce suficientemente a los adultos mayores como un grupo social heterogéneo. La población de la Unión Europea está envejeciendo. Según los informes de la Comisión Europea, la discriminación por edad en Europa está muy extendida. Por tanto, se debe transformar el concepto de sistema de trabajo y jubilación, así como la percepción de los adultos mayores. La discriminación contra los adultos mayores y diversas formas de desigualdad se ven agravadas por la pandemia de COVID-19.

Palabras-clave: Adultos mayores. Derechos. Identidad. Heterogéneo. Unión Europea.

\section{REFERENCES}

BARRET, A. Socioeconomic status and age identity: The role of dimensions of health in the subjective construction of age. Journal of Gerontology: Social Sciences, v. 58, n. 2, p. 101-109, 2003.

BARROSO, J. M. A New Narrative for Europe. European Commission Press Release Database, 2013. Available at: http://europa.eu/rapid/press-release_SPEECH-13-357_ en.htm Accessed on 5 February 2018.

BAVEL, J. J. V.; BAICKER, K.; BOGGIO, P. S. et al. Using social and behavioral science to support COVID-19 pandemic response. Nat Hum Behav, v. 4, p. 460-471, 2020.

CALLAHAN, C. Terminating treatment: Age as a standard. The Hastings Center Report, v. 17, p. 21-25, 1987.

CESARI, M.; PROIETTI, M. COVID-19 in Italy: Ageism and decision making in a pandemic. Journal of the American Medical Directors Association, v. 21, n. 5, p. 576577,2020 .

CHANGING THE NARRATIVE. From frameworks to groundworks. Available at: https://changingthenarrativeco.org/whos-involved/. Accessed on 8 April 2018.

COMMUNICATION COM (2009) 180. Dealing with the impact of an ageing population in the EU (2009 Ageing Report). Brussels: European Commission, 2009. Available at: ec.europa.eu/social/main.jsp?langld=en \&catld=89..500. Accessed on $28 \mathrm{July}$ 2011. 
COSTA-FONT, J; NORTON, E. C; SICILIANI, L. The future of long-term care: A public policy assessment of funding and organization. Vox - CEPR's Policy Portal, 2017. Available at: https://voxeu.org/article/role-government-providing-long-term-care. Accessed on 14 March 2018.

COUNCIL OF EUROPE. Discrimination against Women in the workforce and the workplace, 2005. Available at: http://assembly.coe.int/Documents/AdoptedText/pa05/ erec1700.htm. Accessed on 5 November 2010.

DESCARTES, R. Meditations on first philosophy, trans. by John Veitch, 1901. Available at: http://www.wright.edu/ charles.taylor/descartes/intro.html. Accessed on 2 January 2015.

EC. EUROPA.EU. People in the EU - statistics on an aging society, 2018a. Available at: http://ec.europa.eu/eurostat/statistics-explained/index.php/People_in_the_ EU_\%E2\%80\%93_statistics_on_an_ageing_society. Accessed on 17 November 2017.

EC. EUROPA.EU. Population structure and ageing - statistics, 2018b. Available at: explained.http://ec.europa.eu/eurostat/statistics-explained/index.php/Population_ structure_and_ageing. Accessed on 17 November 2017.

EC. EUROPA.EU. Population projections at national level (2015-2080), 2018c. Available at: http://ec.europa.eu/eurostat/web/population-demography-migrationprojections/population-projections-/database. Accessed on 18 November 2017.

EQUINET. UN open-ended working group on ageing, 2019. Available at: https:// equineteurope.org/2019/fighting-discrimination-on-the-ground-of-age-in-the-eupresented-at-un/. Accessed on 2 September 2019.

EUROPEAN COMMISSION. Age discrimination is widespread across the European Union. Tackling Discrimination. Brussels: European Commission, 2009a.

EUROPEAN COMMISSION. 2009 Ageing communication: A renewed strategy for tackling Europe's demographic challenge. Brussels: European Commission, 2009b. Available at: ec.europa.eu $/$ social $/$ main.jsp?langld=en\&catld $=89 . .500$. Accessed on 10 September 2011.

EUROPEAN SENIORS' UNION. Annual report, 2016. Available at: http://esu-ep.eu/ wp-content/uploads/2017/02/Annual_report_2016_EN-final.pdf. Accessed on 10 March 2018.

EUROPEAN SENIORS' UNION. European Seniors' Union, 2018. Available at: http://esu-ep.eu/. Accessed on 10 March 2018.

EUROPEAN UNION. Charter of the fundamental rights of the European Union, 2020. Available at: https://www.europarl.europa.eu/charter/pdf/text_en.pdf. Accessed on 5 March 2018. 
EUROSTAT. Active ageing and solidarity between generations, 2012. Available at: https://ec.europa.eu/eurostat/documents/3217494/5740649/KS-EP-11-001-EN. PDF/1f0b25f8-3c86-4f40-9376-c737b54c5fcf. Accessed on 3 April 2018.

EUROSTAT. People in the EU: Who are we and how do we live?, 2015. Available at: https://ec.europa.eu/eurostat/documents/3217494/7089681/KS-04-15-567-EN-N. pdf/8b2459fe-0e4e-4bb7-bca7-7522999c3bfd. Accessed on 9 February 2018.

EUROSTAT. People in the EU - statistics on an aging society, revised 18 November 2019. Available at: https://ec.europa.eu/eurostat/statistics-explained/index. php?title=People_in_the_EU_-_statistics_on_an_ageing_society\&oldid=458862. Accessed on 15 December 2019.

EUROSTAT. Population structure and aging, 2020. Available at: https://ec.europa.eu/ eurostat/statistics-explained/index.php/Population_structure_and_ageing. Accessed on 3 January 2021.

FARGUES, P. International migration and Europe's demographic challenge. EU-US Immigration Systems 2011/09, Robert Schuman Centre for Advanced Studies. Florence: European University Institute, 2011.

FOUCAULT, M. The archaeology of knowledge. New York: Pantheon Books, 1972.

FRASER, S.; LEGACÉ, M.; BONGUÉ, B.; NDEYE, N.; GUYOT, J.; BECHARD, L.; GARCIA, L.; TALER, V. Ageism and COVID-19: What does our society's response say about us? Age and Ageing, 2020. Available at: https://www.ncbi.nlm.nih.gov/pmc/ articles/PMC7239227/. Accessed on 1 September 2020.

GIDDENS, A. Europe in the global age. Cambridge: Polity Press, 2007.

GRAF, N.; BROWN, A.; PATTEN, E. The narrowing, but persistent, gender gap in pay. Pew Research Center, 2019. Available at: https://www.pewresearch.org/facttank/2019/03/22/gender-pay-gap-facts/. Accessed on 2 December 2019.

HUDSON, R. Life on the edge: Navigating the competitive tensions between the "social" and the "economic" in the social economy and in its relations to the mainstream. Journal of Economic Geography, v. 9, p. 493-510, 2009.

HREA. The rights of the aged, 2003. Available at: http://www.hrea.org/index.php?baseid=162 Accessed 2 January 2012.

IVIC, S. Demographic change in the European Union: A challenge to EU citizenship. Review of International Affairs, v. XLVII, n. 58, p. 122-140, 2015.

IVIC, S. European identity and citizenship: Between modernity and postmodernity. London: Palgrave Macmillan, 2016.

JECKER, N. S. Disenfranchising the elderly from life-extending medical care. Public Affairs Quarterly, v. 2, n. 3, p. 51-68, 1988. 
LOCKE, J. An essay concerning human understanding, V. I. Oxford: Oxford University Press, 1975

MÉGRET, F. The human rights of the elderly: An emerging challenge, 2010. Available at: www.cardi.ie/userfiles/Human20\%Rights20\%of20\%the20\%Elderly.pdf . Accessed on 18 January 2012.

MEISNER, B.A. Are you OK, boomer? Intensification of ageism and intergenerational tensions on social media amid COVID-19. Leisure Sciences, 2020. Available at: https:// doi.org/10.1080/01490400.2020.1773983. Accessed on 1 September 2020.

NOBLE, B. Political party analysis: 50plus (Netherlands), 2017. Available at: https:// brendan-noble.com/political-party-analysis-50plus-netherlands/. Accessed on 8 June 2018.

PHELAN, A. Elder abuse, ageism, human rights and citizenship: Implications for nursing discourse. Nursing Inquiry, v. 15, n. 4, p. 320-329, 2008.

PHILLIPSON, C.; BIGGS, S. Modernity and identity: Themes and perspectives in the study of older adults. Journal of Aging and Identity, v. 3, n. 1, p. 11-23, 1998.

PIETERS, J. 50Plus reveals election campaign: More elderly rights and regulated cannabis. NL Times, 2016. Available at: https://nltimes.nl/2016/08/23/50plus-revealselection-campaign-elderly-rights-regulated-cannabis. Accessed on 23 December 2017.

SCHALK, R.; VAN VELDHOVEN, M. et al. Moving European research on work and ageing forward: Overview and agenda. European Journal of Work and Organizational Psychology, v. 19, n.1, p. 76-101, 2010.

SHAFFER, V. A.; FOCELLA, E. S.; HATHAWAY, A.; SCHERER, L. D., ZIKMUNDFISHER, B. On the usefulness of narratives: An Interdisciplinary review and theoretical model. Annals of Behavioral Medicine, v. 52, n. 5, p. 429-442, 2018.

UNITED NATIONS. Universal declaration on human rights, 1948. Available at: https:// www.ohchr.org/en/udhr/documents/udhr_translations/eng.pdf. Accessed on 5 March 2018.

UNITED NATIONS. Everyone included: Social impact of COVID-19, 2020.

Available at: https://www.un.org/development/desa/dspd/everyone-included-covid-19. html. Accessed on 12 June 2020.

WEEDON, C. Feminist practice and poststructuralist theory. Cambridge: Blackwell, 1996.

WIERINGA, S. E. Rethinking gender planning: A critical discussion of the use of the concept of gender. Gender, Technology and Development, v. 2, n.3, p. 349-371, 1998. YOUNG, I. M. Justice and the politics of difference. Princeton: Princeton University Press, 1990.

Recebido: 21/01/2021

Aceito: 03/3/2021 